\title{
In vitro mass multiplication of Cymbidium iridioides D.Don- a medicinal orchid from Arunachal Pradesh, India
}

\author{
Jumter Nyorak ${ }^{1}$ and Chandra Bdr. Sonar \\ State Forest Research Institute, Orchid Research Centre Tippi-790 114, \\ Arunachal Pradesh, India \\ ${ }^{1}$ Communicating author; e-mail: jumternyorak16@gmail.com
}

[Received 18.05.2020; Revised 21.06.2020; Accepted 23.06.2020; Published 30.06.2020]

\begin{abstract}
The paper describes in vitro mass multiplication of Cymbidium iridioides D.Don., an epiphytic medicinal orchid from Arunachal Pradesh, through seed culture and early seedling development. Murashige and Skoog (MS, 1962) medium supplemented with 6 -Benzyalaminopurine [(BAP) 0.5 $\mathrm{mgL}^{-1}$ ] plus $a$ - Naphthaleneacetic acid [(NAA) $0.5 \mathrm{mgL}^{-1}$ ] proved to be the best for initiating seed germination. It favored high regeneration frequency, early response, and high proliferation rate in protocorm formation. Plantlets with roots $(4-7$ roots per plant)) were obtained on MS medium supplemented with BAP $(0.5 \mathrm{mg} / \mathrm{l})$, NAA $(0.5 \mathrm{mg} / \mathrm{l})$ and Activated Charcoal $(1 \mathrm{gm} / \mathrm{l})$. Vigorous growth of in vitro seedlings was observed on MS medium supplemented with $10 \%$ coconut water (v/v) plus $10 \%$ banana pulp (w/v). In vitro raised Cymbidium iridioides seedlings recorded $94 \%$ survival in greenhouse conditions.
\end{abstract}

Key words: Cymbidium iridioides, Seed culture, Mass propagation, Medicinal orchid.

\section{INTRODUCTION}

Orchids are nature's most extravagant group of flowering plants distributed throughout the world from tropics to high alpine areas (White \& Sharma 2000). They exhibit incredible range of diversity in shape, size and color of their flowers and, hence, are important aesthetically, medicinally and also regarded as ecological indicators (Joshi et al. 2009). Several orchid species are cultivated for their various economic uses especially in floriculture. Orchids are grown primarily as ornamentals and are valued as cut flowers because of their exquisite beauty and their long lasting blooming periods (Hew et al. 1997) and are linked to culture and customs in many societies including traditional tribes. At the same time, many species of orchids are used as herbal medicines and food (Khasim \& Rao 1999; Kasulo et al. 2009). Although, large populations of orchids are still confined in their natural habitat in many parts of the world, their number in the wild is seriously affected due to their high demand and excessive anthropological disturbances. Many orchid species are threatened due to loss of their natural habitat and indiscriminate collection.

The North-east Indian state Arunachal Pradesh is also housing a large number of naturally occurring orchids and has provided an exhaustive list of 972 species for NE India of which 577 species are known to grow in Arunachal Pradesh (Rao 2018).

Cymbidium iridioides D.Don (PLATE - I) is an epiphytic, sub-tropical orchid species, which has high ornamental as well as medicinal values. Juice from its crushed leaves are used for clotting of blood (stops excessive bleeding) in deep wounds and leaf-paste is used as tonic (Subedi 2011). It is considered to be extra-exotic due to its long lasting beautiful color range and characteristics flowering from September to November. In NE India, so far, the species 
has been recorded from Sikkim, Arunachal Pradesh, Meghalaya, Nagaland, Mizoram and Manipur (Rao 2018). It is found in the sub-tropical and temperate zones of Arunachal Pradesh. This species is reported to be over exploited for commercial and medicinal uses (Joshi \& Joshi 2000; Pant et al. 2002).Consequently, its populations are depleted, became rare and is now restricted to very narrow pockets in the natural habitats. Herbal medicines are the precursors of many common drugs and are getting preferences in the primary health care systems (Jawahar et al. 2008) so are extremely important in biotechnological industries and research for the production of pharmaceutical compounds (Chand et al. 1997).In vitro culture techniques offer viable systems for true-to-type rapid mass multiplication of plants and for germplasm conservation of RET, aromatic and medicinal plants (Arora \& Bhojwani 1989; Sharma et al. 1991; Sudha \& Seeni 1994; Sahoo \& Chand 1998; Karuppusamy \& Pullaiah 2007). The main objective of the present study is to establish a protocol for in vitro mass propagation of Cymbidium iridioides through asymbiotic seed germination to produce maximum number of plantlets for its cultivation and conservation.
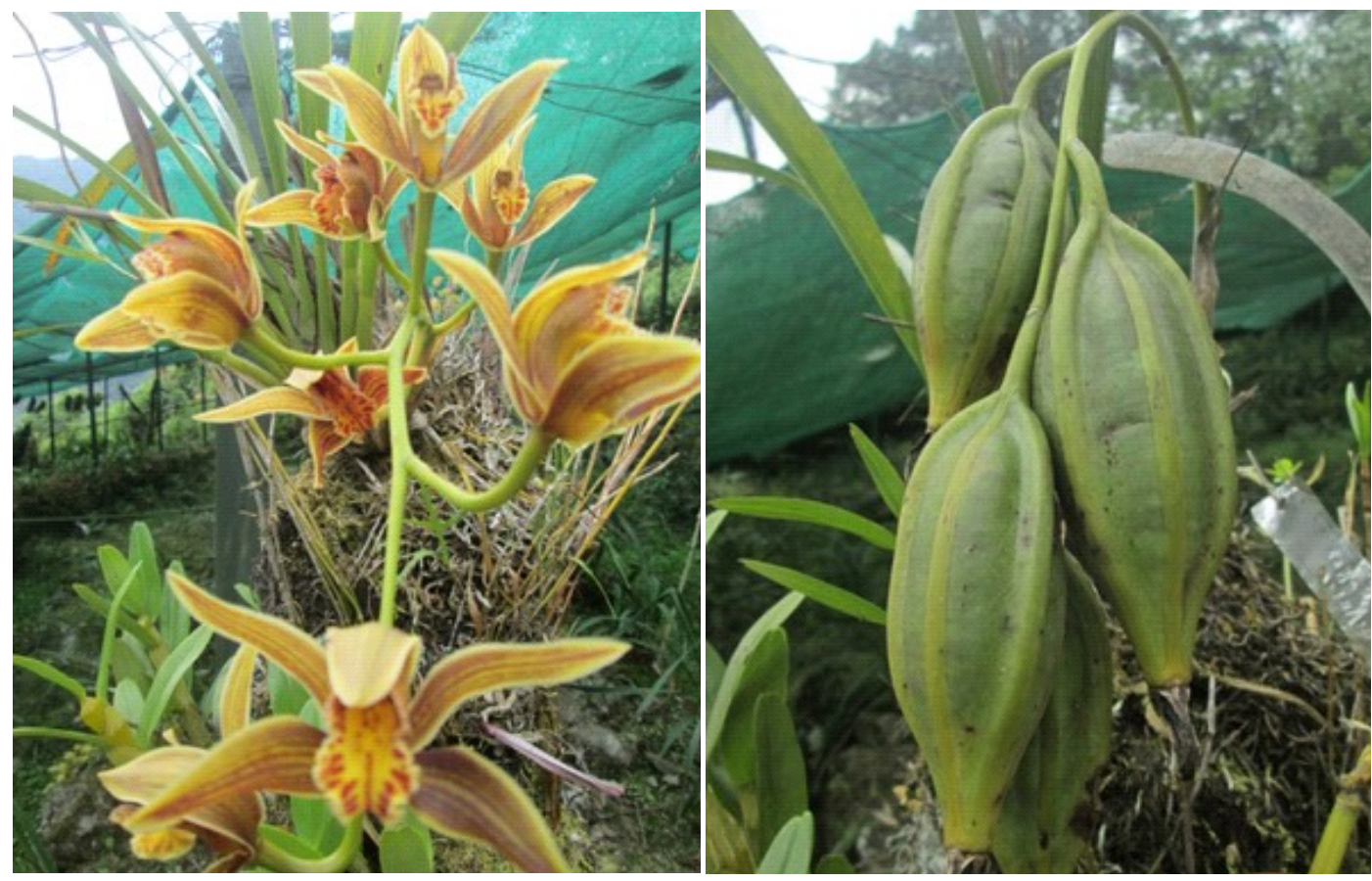

PLATE - I: A. Flowers of Cymbidium iridioides D.Don; B. Seven months old capsules

\section{METHODOLOGY}

The explants used for the present investigation were seven months old mature un-dehisced pods of Cymbidium iridioides collected from the plants under cultivation at Sessa Orchid Nursery, Sessa, West Kameng district of Arunachal Pradesh, India (PLATE - II).

\section{Surface sterilization and Inoculation:}

Green, mature and undehisced capsules of Cymbidium iridioides were used as explants for the present investigation. Green pods were first cleaned with Labolene (detergent) and thoroughly washed in running tap water till the detergent was washed off completely. After that, green 
pods were surface sterilized sequentially by immersing in $10 \%$ Sodium hypochloride $\left(\mathrm{NaOCl}_{2}\right)$ solution for 20 minutes; absolute ethyl alcohol for 10 minutes and finally rinsed thoroughly three times with sterile distilled water. The sterilized capsules were dipped in absolute ethyl alcohol for 2 minutes and then passed through the spirit flame for three times. The capsules were cut longitudinally with the help of a sharp sterile surgical blade to extract the seeds. The seeds were scooped out from the capsules and inoculated by spreading thinly as possible over the surface of the culture medium in conical flasks $(250 \mathrm{ml})$, with each flask containing $40 \mathrm{ml}$ of semi-solid medium.

\section{Culture medium and Culture Conditions:}

In the present study, full and half strength of Murashige and Skoog (MS, 1962), modified Knudson C, (MKc; 1946) and Vacin \& Went (Vw; 1949) medium supplemented with or without plant growth hormones viz, BAP $(0.5 \mathrm{mg} / \mathrm{l})$, NAA $(0.5 \mathrm{mg} / \mathrm{l})$ and organic additives viz. $10 \%$ coconut water (v/v) and $10 \%$ rippened banana $(\mathrm{w} / \mathrm{v})$ were added for in vitro seed germination and seedling development (Table 1). All culture media were gelled with $0.8 \%(\mathrm{w} /$ v) agar and $\mathrm{pH}$ were adjusted at $5.4-5.8$ by using $0.1 \mathrm{~N} \mathrm{NaOH}$ or $\mathrm{HCl}$ prior to autoclaving at $121^{\circ} \mathrm{C}$ for 45 minutes. All cultures were incubated at $23 \pm 2^{\circ} \mathrm{C}$ under $16 / 8 \mathrm{hrs}$ photoperiod of 3000 to 3500 lux light intensity (40 W Fluorescent tubes; Philips India Ltd., Mumbai, India). The experiments were repeated twice. The observations were made regularly and data were recorded accordingly (Table 1).

\section{RESULTS}

The results of the culture cum propagation experiments under different composition of media has been presented in Table 1 below.

Table 1. In vitro seed germination and seedling development of Cymbidium iridioides D.Don

[Abbreviations used: $\mathrm{MKC}=$ Modified Knudson C (MKc, 1946); V\&W= Vacin\& went (Vw, 1949);MS $=$ Murashige and Skoog (MS, 1962); $1 / 2$ MS = Half strength macronutrients; BAP = 6Benzylaminopurine; NAA = á-Naphthalene acetic acid; $\mathrm{AC}=$ Activated charcoal; $\mathrm{Rb}=$ Ripe banana; $\mathrm{Cw}=$ Coconut water; PGR $=$ Plant growth regulators]

\begin{tabular}{|c|c|c|c|c|c|c|c|}
\hline \multirow{2}{*}{$\begin{array}{c}\text { Basal } \\
\text { Medium }\end{array}$} & \multicolumn{2}{|c|}{ PGR $\left(\mathrm{mgL}^{-1}\right)$} & \multirow{2}{*}{$\begin{array}{l}\text { Germination } \\
\text { (in week) }\end{array}$} & \multirow{2}{*}{$\begin{array}{c}\% \text { of } \\
\text { germination }\end{array}$} & \multirow{2}{*}{ Additives } & \multirow{2}{*}{$\begin{array}{l}\text { Seedling } \\
\text { (in } \\
\text { month) }\end{array}$} & \multirow{2}{*}{$\begin{array}{c}\text { Observation/ } \\
\text { remark }\end{array}$} \\
\hline & BAP & NAA & & & & & \\
\hline MKc & & & & 00 & & & No germination \\
\hline $\mathrm{V} \& W$ & & & & 00 & & & No germination \\
\hline $\mathrm{V} \& \mathrm{~W}$ & & & 10 & 30 & $10 \% \mathrm{Cw}$ & & $\begin{array}{c}\text { Germination } \\
\text { favoured }\end{array}$ \\
\hline MS & & & 08 & 70 & & & $\begin{array}{c}\text { Germination } \\
\text { favoured }\end{array}$ \\
\hline $1 / 2 \mathrm{MS}$ & & & 08 & 65 & & & $\begin{array}{l}\text { Germination } \\
\text { favoured }\end{array}$ \\
\hline MS & 0.5 & 0.5 & 06 & 96 & & & $\begin{array}{c}\text { Germination, } \\
\text { growth, } \\
\text { \& development }\end{array}$ \\
\hline MS & 0.5 & 0.5 & & & $1 \mathrm{gm} \mathrm{AC}$ & 2 & $\begin{array}{c}\text { Plantlets } \\
\text { developed roots }\end{array}$ \\
\hline MS & & & & & $\begin{array}{r}10 \% \mathrm{Cw} \\
+10 \% \mathrm{Rb} \\
\end{array}$ & 4 & $\begin{array}{l}\text { Vigorous growth } \\
\text { of seedlings }\end{array}$ \\
\hline
\end{tabular}



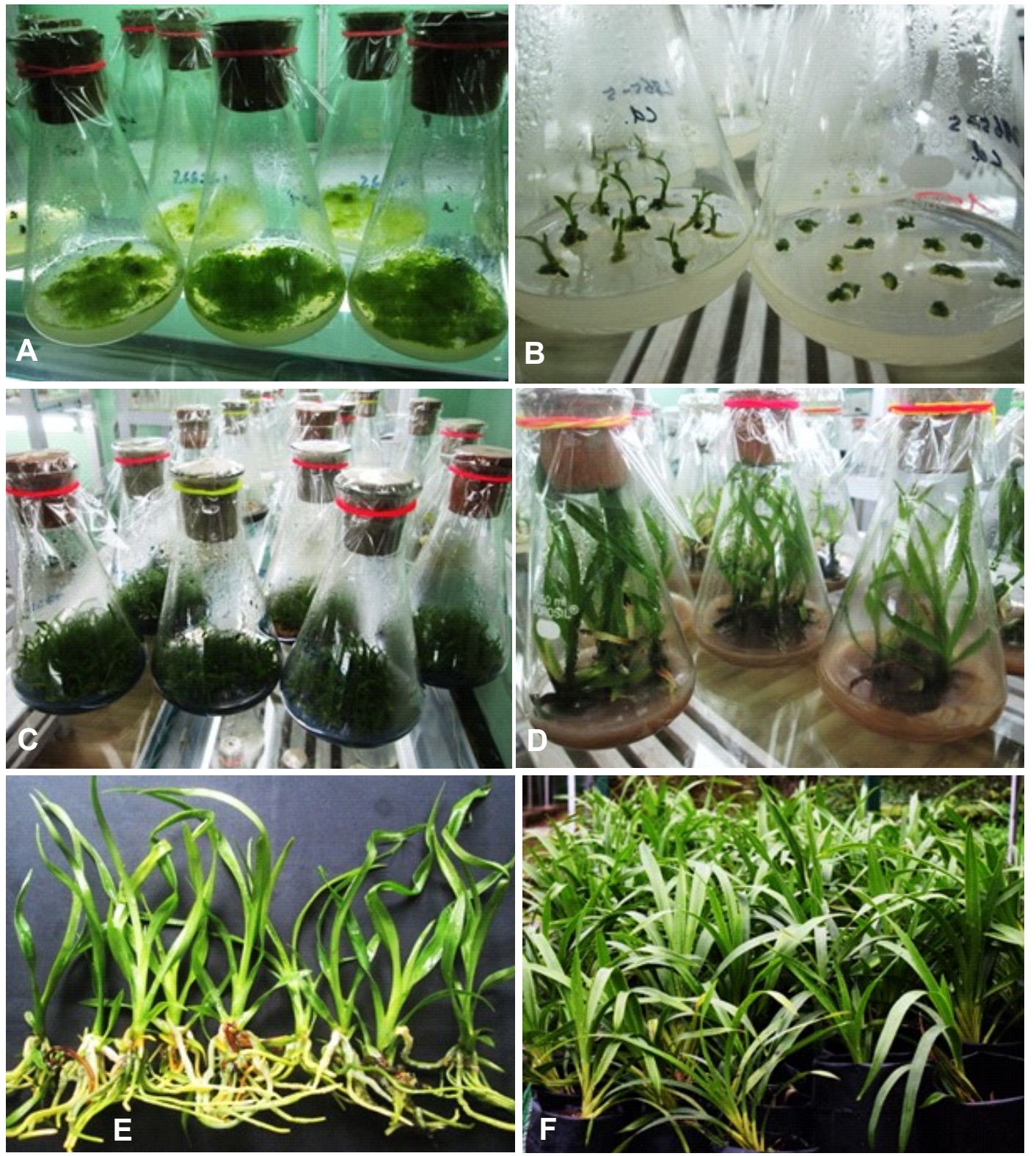

PLATE II. Different stages of in vitro seed germination and seedling development of Cymbidium iridioides D.Don: A. Mature seeds turned into small spherules to protocorms on full strength MS + BAP $(0.5 \mathrm{mg} / \mathrm{l})+\mathrm{NAA}(0.5 \mathrm{mg} / \mathrm{l})$; B. Protocorms with primordial leaf on same fresh primary culture media; C. Development of small shoots on MS + BAP (0.5 $\mathrm{mg} / \mathrm{l})+\mathrm{NAA}(0.5 \mathrm{mg} / \mathrm{l}+1 \mathrm{gm} / 1 \mathrm{Ac} ;$ D. Vigorous growth and development of plantlets on MS $+10 \% \mathrm{Cw}+10 \% \mathrm{Rb} ; \mathbf{E}$. Deflasked planlets; F. Acclimatized seedlings

\section{DISCUSSION}

Varied response of Cymbidium iridioides seeds cultured on V\&W, MKc, V\&W supplemented with $10 \%$ coconut water (v/v), $1 / 2$ MS, MS and MS basal media supplemented with BAP $(0.5 \mathrm{mg} / \mathrm{l})$ and NAA $(0.5 \mathrm{mg} / \mathrm{l})$, was recorded (Table 1$)$. MS medium with or without growth regulators was found to be effective for the germination of mature seeds whereas 
Jumter Nyorak \& Chandra Bdr. Sonar 53

MKc and V\&W without additives were found to be ineffective. In MS medium seeds started germination after two weeks of inoculation. In half and full strength of MS basal media, the visible sign of germination was observed as the swollen yellowish green spherule like protocorms developed within 8 weeks of primary culture. The first primordial leaf was developed in 12 weeks of culture, and by 16 weeks, roots were developed when protocorms with leaf primordial were sub-cultured on the same fresh basal media. Although, MS, $1 / 2 \mathrm{MS}$ and V\&W supplemented with $10 \%$ coconut water (v/v) (Table 1) favoured seed germination, the rate of seed germination was less in comparison to MS medium supplemented with BAP $(0.5 \mathrm{mg} / \mathrm{l})$ and NAA $(0.5 \mathrm{mg} / \mathrm{l})$ where the initiation of seed germination was observed within 6 weeks of primary culture and around $96 \%$ of seeds were successfully germinated. The germination of seeds and growth of protocorms were variously affected depending on the concentrations and combinations of growth regulators. Growth of protocorms were vigorous on MS media supplemented with BAP $(0.5 \mathrm{mg} / \mathrm{l})$ and NAA $(0.5 \mathrm{mg} / \mathrm{l})$ (PLATE - II, Figure A).Protocorms obtained on germination medium were subcultured onto $1 / 2 \mathrm{MS}, \mathrm{Vw}$ and MS supplemented with BAP $(0.5 \mathrm{mg} / \mathrm{l})$, NAA $(0.5 \mathrm{mg} / \mathrm{l})$ and $1 \mathrm{gm}$ Activated charcoal for further development. Though proliferation and plantlet development of protocorms were observed in all three tested media, MS basal medium fortified with optimum cytokinins and auxins proved more effective. Such promoting effects of cytokinins and auxins for regeneration of PLBs and multiplication thereof have been reported earlier by Gangaprasad et al. (1999) and Vij et al. (2000). Vigorous growth and further proliferation of plantlets were observed when small plantlets from the primary cultures were transferred to full strength MS basal medium supplemented with $10 \%$ coconut water(v/v) and $10 \%$ ripe banana Pulp (w/v) (FPLATE - II, Figure D). Well-rooted plantlets were planted in poly bags containing mixtures of decomposed wood and dried leaf-mould with top soil and transferred to a Green House for acclimatization (PLATE - II, Figures E \& F). About $96 \%$ of in vitro raised seedlings survived and established in the green house conditions.

In the present studies, a combination containing cytokinins and auxin $[\mathrm{BAP}(0.5 \mathrm{mg} / \mathrm{l})+$ NAA $(0.5 \mathrm{mg} / \mathrm{l})]$ proved to be the best. The requirement of synergistic combinations of cytokinins and auxins for stimulating proliferation and further differentiation is well reported in orchid literature (Kanika \& Vij 2002; Mathews \& Rao 1985; Park et al. 2000; Pathak \& Vij 2001; Seeni \& Latha 1992, 2000; Tanaka \& Sakanishi 1997; Vij et al. 2002). A successful attempt was made to compare the in vitro seed germination and their subsequent differentiation of $C$. iridioides on $1 / 2 \mathrm{MS}, \mathrm{MS}, \mathrm{Vw}, \mathrm{MKc}$ and MS fortified with BAP $(0.5 \mathrm{mg} / \mathrm{l})$ and NAA $(0.5 \mathrm{mg} / \mathrm{l})$. Although $1 / 2$ MS, MS and $\mathrm{Vw}_{\mathrm{w}}$ basal media with $10 \% \mathrm{Cw}(\mathrm{v} / \mathrm{v})$ showed seed germination, higher percentage of germination in shorter period was observed on full strength MS basal medium supplemented with BAP $(0.5 \mathrm{mg} / \mathrm{l})$ and NAA $(0.5 \mathrm{mg} / \mathrm{l})$. Hormone free full and half of media took longer period for germination. Hence, in conclusion, MS medium was found to be the best in terms of vigorous growth, production of large protocorms and time requirements especially when medium was supplemented with optimum growth hormones. Thus, this protocol might be useful for selection of best condition for in vitro mass multiplication for ex-situ conservation as well as large scale cultivation of Cymbidium iridoides D.Don - a valuable medicinal orchid species.

\section{Acknowledgements}

The authors wish to acknowledge Dr. Jambey Tsering, Scientist In-charge, Smt. Yani Nyodu RFO Orchid Research Centre Tippi for encouragement and valuable suggestions. Sincere thanks are also due to Shri K.S. Rab, Technical Asstt., SFRI for providing materials for micropropagation and Sri Khyanjeet Gogoi for his encouragement for mass multiplication of medicinal orchids. 


\section{LITERATURE CITED}

Arora, R. \& Bhojwani, S.S. 1989. In vitro propagation and low temperature storage of Saussurea lappa C.B. Clarke - An endangered medicinal plant. Plant Cell Rep. 8: $44-47$.

Chand, S.; Sahrawat, A.K. \& Prakash, D.V.S.S.R. 1997. In vitro culture of Pimpinella anisum L. (anise). J. Pant Biochem. Biotech. 6: 1 - 5.

Gangaprasad, A.N.; Decruse, S.W.; Seeni, S. \& Menon, S. 1999. Micropropagation and restroration of the endangered Malabar daffodil orchid Ipseamalabarica. Lindleyana, 14(1): $38-46$.

Hew, C.S.; Arditti, J. \& Lin, W.S. 1997. Orchid cut-flower production in ASEAN countries. In: Arditti, J. (ed.), Orchid Biol. Rev. Perspect. 6: 363 - 401.

Jawahar, M.; Ravipaul, S. \& Jeyaseelan, M. 2008. In vitro regeneration of Vitex negundo L - a multipurpose woody aromatic medicinal shrub. Plant Tissue Cult. \& Biotech. 18(1): 37 - 42.

Joshi, K.K. \& Joshi, S.D. 2000. Genetic Heritage of Medicinal and Aromatic Plants of Nepal Himalayas. Buddha Academy Publisher and Distributors Pvt., Kathmandu, Nepal.

Joshi, G.; Tewari, L.M.; Lohani, N.; Upreti, K.; Jalal, J.S. \& Tewari, G. 2009. Diversity of orchids on Uttarakhand and their conservation strategy with special reference to their medicinal importance. Rep. Opin. 1: 47 - 52.

Karuppusamy, S. \& Pullaiah, T. 2007. In vitro shoot multiplication of Bupleurum distichophyllum Wight. A native medicinal plant of south India. Plant Tissue Culture and Biotechnology 17(2): $115-124$.

Kanika \& Vij, S.P. 2002. Micropropagation of Vanda coerulea R. Br. (Orchidaceae) through leaf segment culture. Ann. Agric. Res. New Series, 23(2): 300 - 303.

Kasulo, V.; Mwabumba, L. \& Munthali, C. 2009. A review of edible orchids in Malawi. J. Hortic. For. 1: 133 - 139.

Khasim, S. \& Rao, P.R.M. 1999. Medicinal importance of orchids. The Botanica 49: 86-91.

Knudson, L. 1946. A new nutrient solution for the germination of orchid seed. Amer. Orchid Soc.Bull., 15: $214-217$.

Mathews, V.H. \& Rao, P.S. 1985. In vitro culture of Vanda hybrid (Vanda TMA x Vanda Miss Joaquim) I. Studies in protocorm explants. Proc. Indian Natn. Sci. Acad. B51(1): $96-103$.

Murashige, T. \& Skoog, F. 1962. A revised medium for rapid growth and bioassays with tobacco tissue cultures. Physiol. Plant., 15: 473.

Pant, B.; Chaudhary, R.P.; Subedi, A. \& Shakya, L.R. 2002. Nepalese Himalayan Orchids and the conservation priorities. In: Proceeding of International Seminar on Mountains. Royal Nepal Academy of Science and Technology, Kathmandu. Pp. 485 - 495.

Park, S.Y.; Murthy, H.N. \& Paek, K.Y. 2000. Mass multiplication of protocorm-like bodies using bioreactor system and subsequent plant regeneration in Phalaenopsis. Plant Cell Tiss. Org.Cult., 63: $67-72$.

Pathak, P. \& Vij, S.P. 2001. In vitro regeneration of Papilionanthe teres (Roxb.) Schltr.: Utility of foliar explants. In: Nagata, H. \& Ichihashi, S. (eds.), Proc. $7^{\text {th }}$. Asia Pacific Orchid Conference Organizing Committee, APOC7, Nagoya. Pp. 226 - 227.

Rao, A.N. 2018. Orchid diversity of North-east India - classification, analysis and conservation issues. In: Das, A.P. \& Bera, S. (eds.), Plant Diversity in the Himalaya Hotspot Region. Vol. II. Bishen Singh Mahendra Pal Singh, Dehra Dun. ISBN: 97881-211-0985-7. Pp. $821-863$. 
Sahoo, Y. \& Chand, P.K. 1998. Micropropagation of Vitex negundo L. a woody aromatic medicinal shrub through high frequency of axillary shoot proliferation. Plant Cell Rep. 18: $301-307$.

Seeni, S. \& Latha, P.G. 1992. Foliar regeneration of the endangered red Vanda, Renanthera imschootiana Rolfe (Orchidaceae). Plant Cell Tiss. Org. Cult., 29: 167 - 172.

Seeni, S. \& Latha, P.G. 2000. In vitro multiplication and ecorehabilitation of the endangered Blue Vanda. Plant Cell Tiss. Org. Cult., 61: $1-8$.

Sharma, N.; Chandel, K.P.S. \& Srivastava, V.K. 1991. In vitro propagation of Coleus forskoblii Briq. A threatened medicinal plant. Plant Cell Rep. 10: 67 - 70.

Subedi, A. 2011. New species, pollinator interactions and pharmaceutical potential of Himalayan orchids. Ph.D. Thesis, Leiden University, The Netherlands.

Sudha, G.C. \& Seeni, S. 1994. In vitro multiplication and field establishment of Adhatoda beddomei C.B. Clarke - A rare medicinal plant. Plant Cell Rep. 13: 2003 - 2007.

Tanaka, M. \& Sakanishi, Y. 1997. Clonal propagation of Phalaenopsis by leaf tissue culture. Am. Orchid Soc. Bull., 46: 733-37.

Vacin, E.F. \& Went, F.W. 1949. Some pH changes in nutrient solutions. Bot. Gaæ: 110: 605 - 613.

Vij, S.P.; Kher, A. \& Gupta, A. 2000. Orchid micropropagation. In: Chadha, K.L.; Ravindran, P.N. \& Sahijram, L. (eds.) Biotechnology in Horticultural and Plantation Crops. Malhotra Publishing House, New Delhi. Pp. 598 - 641.

Vij, S.P.; Kaur, P.; Kondo, K.; Pathak, P. \& Gupta, A. 2002. Regeneration competence of orchid leaves: A study in vitro. In: Vij, S.P.; Kondo, K.; Sharma, M.L. and Gupta, A. (eds.), Plant Genetic Diversity: Exploration, Evaluation, Conservation. Affiliated East-West Press, New Delhi. Pp. 289 - 306.

White, K.J. \& Sharma, B. 2000.Wild orchids in Nepal: the guide to the Himalayan orchids of the TribhuvanRajpath andChitwan Jungle: White Lotus press, Bangkok, Thailand. 